\title{
Silymarin Accumulation in Silybum marianum Suspension Culture via Precursor Feeding
}

\author{
Sabah Anwar Hassanen, Mohamed Ismail Diab, Ghada Abd El-Moneim Hegazi*, \\ Gamil Rayan Abou El-Dis \\ Tissue Culture Unit, Department of Genetic Resources, Desert Research Center, 11753 El-Matareya, Cairo, Egypt
}

\begin{abstract}
Silymarin and phenolic compounds have great pharmaceutical applications, particularly as hepatoprotective agents. Silymarin content in Silybum marianum wild populations is low with significant differences between the individuals and the areas of these populations decreased due to the increasing interest in the plant. Therefore, cell suspension culture technique is an alternative and sustainable procedure for the bioproduction and conservation of the plant. The aim of the present study was the production of silymarin and certain phenolic compounds from $S$. marianum cell suspension cultures by the supplementation of the precursor amino acid; L-phenylalanine. Seeds were collected from wild plants at Alexandria desert road and germinated in vitro. Seedlings root segments were cultured on Murashige and Skoog basal medium supplemented with $4.55 \mu \mathrm{M}$ 2,4-dichlorophenoxy acetic acid and $4.44 \mu \mathrm{M}$ 6-benzyladenine for the induction and proliferation of callus. Cell suspension cultures were established in the same medium supplemented with Lphenylalanine at different concentrations (302.68, 605.36 and 908.05 $\mu \mathrm{M}$ ). L-Phenylalanine elevated the cells biomass and the accumulation of silymarin and some phenolic compounds. The significantly highest silymarin accumulation reached $66.33 \%$ increase compared to the control. This study highlights the potential of L-phenylalanine for the in vitro production of silymarin-rich extracts and protecting the environment by preventing the overcollection of the plant.
\end{abstract}

Keywords: Flavonolignans; in vitro cell culture; Milk thistle; Phenolic compounds; Phenylalanine.

\section{INTRODUCTION}

Silybum marianum (L.) Gaertn. is commonly known as milk thistle and is one of the most essential medicinal plants from the family Asteraceae. The plant is native to the Mediterranean region. In Egypt, it occurs naturally in Oasis of Libyan desert, Western Mediterranean coastal region, the Ithemic desert; ElTih and North of Wadi Tulimat, Nile region, along canal banks, roadsides and waste lands (Boulos, 2002). $S$. marianum has a strong hepatoprotective activity (Abenavoli et al., 2018), it contains active constituents with significant antioxidant and anti-inflammatory potentials, having important pharmaceutical and cosmetic applications (Shah et al., 2019).

The main active constituents in $S$. marianum are flavonolignans and phenolic compounds (Bhattacharya, 2020). Flavonolignans are natural phenolics that include a flavonoid and a lignan. Silymarin is the prominent bioactive compound in the plant and is a mixture of flavonolignans of which the most abundant components are silybin $\mathrm{A}$ and $\mathrm{B}$, isosilybin $\mathrm{A}$ and $\mathrm{B}$, silychristin and silydianin together with the flavonoid taxifolin (Csupor et al., 2016; Shah et al., 2019). Silymarin is a commonly used plant-derived hepatoprotective agent (Vargas-Mendoza et al., 2014). It is optimum for the treatment of liver and gallbladder diseases such as cirrhosis, jaundice and hepatitis (Colica et al., 2017). It protects liver and kidney tissues against toxins including the toxic effect of drugs such as chemo- and radiotherapy (Csupor et al., 2016). Due to the high free radical scavenging activity of silymarin, it has antioxidant activities and neutralizes the effect of oxidative damage and protects the tissues
(Soto et al., 2010). Among the other most desirable medicinal properties of silymarin are its anti-cancer, anti-inflammatory, anti-arthritic and anti-viral activities (Bijak, 2017; Bijak et al., 2017). The phenolic compounds produced by the plant are natural protective antioxidant agents (Abbasi et al., 2010; Hano and Tungmunnithum, 2020), hence antioxidant activity is strongly associated to the polyphenolic content of a plant (Fidranny et al., 2015).

The increasing demand for the active constituents from $S$. marianum severely affecting the availability of the plant populations (Ahmad et al., 2008). Moreover, successful trials for its domestication and breeding are scarce (Ram et al., 2005). Seed germination is poor and seedling growth rate is low, depending on numerous environmental and biological factors (Abbasi et al., 2010). In general, conventional cultivation of $S$. marianum is vulnerable for some reasons, especially because of the spiny leaves and flowers, which makes the handling of the plants very difficult and causes the damage of the harvesting machines leading to the reduction of yield. Also, field-grown plants are affected by environmental, seasonal and genetic variations as well as pollutants and herbicides that negatively affect the medicinal value of the plants (Shah et al., 2021).

Due to the increasing interests in $S$. marianum, alternative and sustainable bioproduction procedures other than conventional field cultivation of the plant are required. Tissue and cell culture techniques could be extremely useful for solving these complications. The in vitro production of plant secondary metabolites is achieved under controlled conditions and could be modified for the optimum growth and production even outside the growth season of the plant; therefore, it is 
not affected by climatic changes or soil conditions and would be free of infections by microorganisms or insects (Geng et al., 2001). Cell suspension culture offers advantages over chemical synthesis of bioactive compounds because they are difficult to be synthesized with chemical procedures and have harmful side effects on the human health rather than natural biproducts (Zhao and Verpoorte, 2007).

Precursor feeding strategy stimulates bioactive compounds accumulation effectively in callus and cell cultures of many plants; including $S$. marianum (Tůmová et al., 2006; Rahimi et al., 2011; Firouzi et al., 2013; Elhaak et al., 2016). Flavonoids biosynthetically are derived from phenylalanine and malonylCoA through the phenylpropanoid pathway (Matkowski, 2008). Elhaak et al. (2016) studied the effect of phenylalanine on the accumulation of silymarin in callus tissue of S. marianum and obtained the maximum accumulation of $31.4 \%$, compared to control, with $25 \mu \mathrm{M}$ phenylalanine. Also, Rahimi et al. (2011) found that $S$. marianum hairy root culture supplemented with phenylalanine at $100 \mu \mathrm{M}$ was optimal to produce silymarin (1.84-fold higher than that of the control) and $10 \mu \mathrm{M}$ increased the root biomass (0.43 g) 1.89-fold compared to the control. Firouzi et al. (2013) found that silymarin was 8.6 times higher than control in cell suspension culture from hypocotyl in medium enriched with phenylalanine, methyl jasmonate and yeast extract together. However, Tůmová et al. (2006) used the precursor coniferyl alcohol for feeding $S$. marianum cell suspension cultures and it enhanced the content of some components of silymarin complex in vitro.

Silymarin occurs in the entire $S$. marianum plant, but it is concentrated in the fruit and seed (Valková et al., 2020). Fruit extract contains 70-80\% silymarin representing $1.5-3 \%$ of the dry weight (Bijak, 2017; Valková et al., 2020). In Egypt, AbouZid et al. (2016) reported that silymarin content in $S$. marianum fruits of wild populations is low and varies between 0.06-2.19\% with significant differences in the yield between populations. Therefore, the present study aimed to stimulate the increase of silymarin and phenolic compounds biosynthesis in the Egyptian S. marianum cell suspension culture, using the precursor amino acid phenylalanine, for the mass production of the bioactive compounds and consequently conserving the plant from overexploitation.

\section{MATERIALS AND METHODS}

The present study was conducted in Tissue Culture Laboratories, Desert Research Center, El-Matareya, Cairo, Egypt.

\section{Plant material}

Seeds of $S$. marianum were collected from wild plants grown naturally in Alexandria desert road. Plant specimens were identified by Dr. Omran Ghaly, Head of Plant Taxonomy Unit, Desert Research Center, Egypt. Voucher Herbarium specimen was given the number CAIH-1029-R and deposited in the Herbarium of Desert Research Center (CAIH).

\section{Seed surface sterilization and germination}

Seeds were washed under running tap water with liquid detergent (Pril) and Dettol $(4.8 \%$ w/v chloroxylenol) for $30 \mathrm{~min}$, then surface sterilized in $80 \%$ $(\mathrm{v} / \mathrm{v})$ commercial bleach solution (Clorox containing $5.25 \%$ sodium hypochlorite) for $15 \mathrm{~min}$ and finally rinsed five times with sterile distilled water. Seeds were soaked in $500 \mathrm{mg} \mathrm{l}^{-1}$ gibberellic acid $\left(\mathrm{GA}_{3}\right.$; filter sterilized) for $24 \mathrm{~h}$, then cultured on ready-made Murashige and Skoog (MS; Murashing and Skoog, 1962) basal medium (Duchefa, Haarlem, the Netherlands) supplemented with $3 \%(\mathrm{w} / \mathrm{v})$ sucrose and $0.01 \%(\mathrm{w} / \mathrm{v})$ myo-inositol (Fluka AG, Switzerland) for in vitro germination. The $\mathrm{pH}$ of the medium was adjusted to 5.7-5.8 and solidified with $0.275 \%(\mathrm{w} / \mathrm{v})$ phytagel (Duchefa), before autoclaving at a pressure of $1.06 \mathrm{~kg}$ $\mathrm{cm}^{-2}$ and $121^{\circ} \mathrm{C}$ for $20 \mathrm{~min}$. Seeds were incubated in the dark for two weeks, and then transferred to a $16-\mathrm{h}$ photoperiod under white fluorescent light (2500-3000 lux) at $24 \pm 2^{\circ} \mathrm{C}$. After 30 days of incubation, the seeds were germinated, and root segments from seedlings were used as explants for callus induction.

\section{Induction and proliferation of callus cultures}

Root segments $(1 \mathrm{~cm})$ were cultured on MS basal medium supplemented with $3 \%(\mathrm{w} / \mathrm{v})$ sucrose, $0.01 \%$ (w/v) myo-inositol, $4.55 \mu \mathrm{M}$ 2,4-dichlorophenoxy acetic acid (2,4-D) and $4.44 \mu \mathrm{M}$ 6-benzyladenine (BA) for the induction of callus, as reported by Hassanen and Khalil (2013) and Elsawy (2017). All plant growth regulators used in the present study was purchased from Sigma (minimum 90\%, St. Louis, USA). The $\mathrm{pH}$ of the medium was adjusted to 5.7-5.8 and solidified with $0.275 \%$ (w/v) phytagel, before autoclaving. The obtained callus was proliferated by subculturing every 21 days for five times on a fresh medium of the same composition to provide a sufficient source for establishing the cell suspension culture. Callus cultures were incubated under white fluorescent light (2500-3000 lux) at a 16 -h photoperiod and $24 \pm 2{ }^{\circ} \mathrm{C}$.

\section{Establishment of cell suspension cultures \\ Preparation of the cell suspension}

For the preparation of inoculum, homogeneous and friable root-derived callus ( $1.5 \mathrm{~g} \mathrm{FW})$ were cultured in $250 \mathrm{ml}$ Erlenmeyer flasks containing $50 \mathrm{ml}$ of liquid MS basal medium supplemented with $3 \%$ (w/v) sucrose, $0.01 \%(\mathrm{w} / \mathrm{v})$ myo-inositol, $4.55 \mu \mathrm{M} 2,4-\mathrm{D}$ and $4.44 \mu \mathrm{M}$ BA. The $\mathrm{pH}$ of the medium was adjusted before autoclaving as mentioned previously. The cell suspension culture was incubated on a rotary shaking incubator (DAIHAN Scientific, Korea) at a constant agitation of $120 \mathrm{rpm}$ and $24 \pm 2^{\circ} \mathrm{C}$. After seven days of incubation, the cells were filtered using stainless steel sieves and the filtrate containing cells were used to establish the cell suspension culture experiment.

\section{Characterization of cell suspension culture}

The fresh weight (FW) and the percentage of viable cells of suspended cell cultures were recorded at fourday intervals during 36 days of incubation in the described medium and conditions. Fresh weight, as 
gram per $50 \mathrm{ml}$, was determined by weighing the freshly harvested cells after filtration from the medium. Cell number was monitored using the traditional cell counting method by a hemocytometer (Stoddart, 2011). The hemocytometer and its coverslip were prepared by washing with $70 \%(\mathrm{v} / \mathrm{v})$ ethanol and allowed to dry. Trypan blue dye was prepared at a concentration of $4 \%$ in $0.81 \%$ sodium chloride and $0.06 \%$ dibasic potassium phosphate. A mixture of $1: 1(\mathrm{v} / \mathrm{v})$ of the suspended cells and a $0.4 \%$ trypan blue solution was prepared. The mixture was gently mixed and let to stand for 5 min at room temperature, then was loaded into the counting chamber of the hemocytometer. The total number of cells, both viable (unstained) and nonviable (stained) were recorded considering any dilutions made to the cell suspension. The viability percentage of cells was represented by the percentage of unstained cells in the suspension according to the following equation:

$$
\% \text { of viable cells }=\frac{\text { Number of viable cells }}{\text { Total number of cells }} \times 100
$$

\section{Shake-flask culture experiment and precursor feeding}

Cell suspension cultures were established in $250 \mathrm{ml}$ Erlenmeyer flasks containing a total of $50 \mathrm{ml}$ of the liquid-optimized MS basal medium supplemented with $3 \%(\mathrm{w} / \mathrm{v}$ ) sucrose, $0.01 \%(\mathrm{w} / \mathrm{v})$ myo-inositol, $4.55 \mu \mathrm{M}$ 2,4-D and $4.44 \mu \mathrm{M}$ BA. The precursor amino acid; Lphenylalanine (Sigma, min. 90\%, St. Louis, USA) was added to the medium at different concentrations (302.68, 605.36 and 908.05 $\mu \mathrm{M}$ ) for elevating the accumulation of silymarin and some phenolic compounds in the in vitro cell suspension culture. Each flask contained $5 \mathrm{ml}$ of the prepared cell suspension in addition to $45 \mathrm{ml}$ of the culture medium. The control treatment was made without phenylalanine. The medium was adjusted at $\mathrm{pH}$ 5.7-5.8, then autoclaved. Flasks were closed with cotton plugs and two loosely placed layers of aluminum foil to permit gas exchange. The flasks were incubated on the rotary shaker as mentioned above. Cells were collected after 30 days of incubation, filtered using a filter paper and the fresh weight was recorded as g per $50 \mathrm{ml}$. Dry weight (DW; as $\mathrm{g}$ per $50 \mathrm{ml}$ ) was taken after drying the cells in an oven at $45^{\circ} \mathrm{C}$ until a constant weight was obtained. The content of silymarin and phenolic compounds were determined in the dry matter and calculated as percentage $(\%)$ in relation to the dry weight of cells for each treatment.

\section{Determination of secondary metabolites}

\section{Determination of silymarin content}

Cells of $S$. marianum from each treatment were harvested, separated from the medium and dried. Silymarin was extracted according to the method of Cacho et al. (1999) from $0.05 \mathrm{~g}$ of the dry matter with $0.5 \mathrm{ml}$ of $80 \%$ methanol (MeOH; analytical grade) for $30 \mathrm{~min}$ in a water bath at $40^{\circ} \mathrm{C}$. This step was repeated five times, and then the methanolic solutions were collected and evaporated. The dry residue was redissolved in $2 \mathrm{ml} \mathrm{MeOH}$ and kept at $4^{\circ} \mathrm{C}$ in the dark. Silymarin content was measured spectrophotom- etrically using UV/VIS spectrophotometer (ChromTech, model CT-2400, Taiwan). Six dilutions of standard silymarin (Sedico, Egypt) were prepared in $80 \% \mathrm{MeOH}$ for the standard curve. Standard concentrations and sample solutions were scanned in the range of $200-400 \mathrm{~nm}$ to determine the maximum absorbance against $80 \% \mathrm{MeOH}$ as a blank. The maximum absorbance was observed at $255.7 \mathrm{~nm}$ and silymarin concentration was calculated based on the calibration curve for the standards and expressed in percentage $(\%)$.

\section{Determination of phenolic compounds content}

Samples $(0.5 \mathrm{~g})$ of the cell cultures were extracted twice with boiling $\mathrm{MeOH}$ (50 ml for $2 \mathrm{~h}$ ). Determination of certain phenolic compounds was performed by a modified high-performance liquid chromategraphy (HPLC) with a diode-array detector (DAD) method of Ellnain-Wojtaszek and Zgórka (1999), using HPLC-DAD (Merck-Hitachi) and RP-18e column (49250 mm, $5 \mu \mathrm{m}$; Merck). The mobile phase consisted of A- MeOH: $0.5 \%$ acetic acid $(1: 4 \mathrm{v} / \mathrm{v})$; $\mathrm{B}-\mathrm{MeOH}$, at gradient program $\mathrm{B}$ from 0 to $100 \%$, at $25^{\circ} \mathrm{C}$. The injection volume was $10 \mu \mathrm{l}$ at a flow rate of $1 \mathrm{ml} \mathrm{min}^{-1}$ and detection wavelength of $254 \mathrm{~nm}$. Quantification was carried out based on the calibration curves for the standards of the following phenolic compounds: gallic acid, chlorogenic acid, catechin, methyl gallate, caffeic acid, syringic acid, pyro catechol, rutin, ellagic acid, coumaric acid, vanillin, ferulic acid, naringenin, taxifolin, cinnamic acid and kaempferol (Sigma-Aldrich Co., USA). Phenolic compounds concentration was recorded as percentage $(\%)$.

\section{Experimental design and statistical analysis}

The experiments were set up in completely randomized design with at least three replicates per treatment. The significance of differences among means was carried out by Duncan's multiple range test at the 0.05 level. The results were subjected to one-way analysis of variance (ANOVA) using SPSS v.16 (SPSS, Chicago, USA).

\section{RESULTS}

\section{Establishment and characterization of cell suspension culture}

Friable callus was obtained from root explants of seedlings, from in vitro germinated seeds of $S$. marianum, on MS basal medium supplemented with $4.55 \mu \mathrm{M}$ 2,4-D and $4.44 \mu \mathrm{M}$ BA (Fig. 1A). Cell suspension cultures were prepared by the same medium composition (Fig. 1B and C). Fresh weight and viability of suspended cells were significantly affected by the duration of the suspension culture. The curves of cells fresh weight and viability percentage are represented in Fig. (2) and (3). Both curves show a gradual increase in the growth parameter of suspended cells by time. The cells fresh weight reached the maximum value of 3.36 g $50 \mathrm{ml}^{-1}$ after 32 days of incubation, then significantly decreased, while cell viability reached the maximum of $87.24 \%$ at the 16th day, then significantly decreased gradually by further increasing of the duration. 


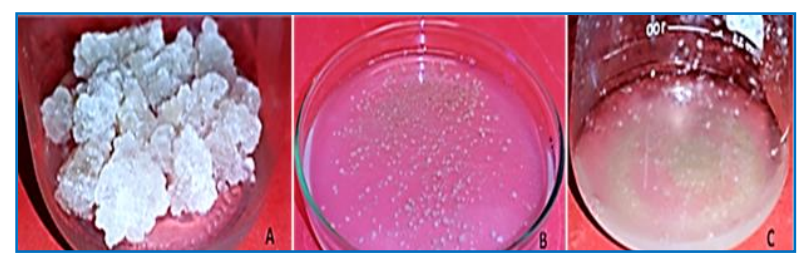

Figure (1): Establishment of the cell suspension cultures of $S$. marianum. A, Callus from root explants on MS basal medium supplemented with $4.55 \mu \mathrm{M}$ 2,4-D and $4.44 \mu \mathrm{M}$ BA; B, Cell suspension on a plate; $\mathrm{C}$, A well-established cell suspension culture in a flask.

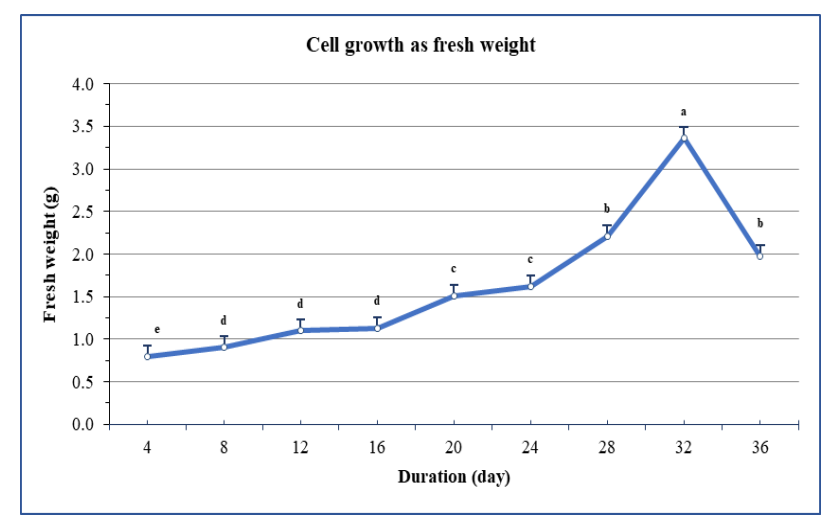

Figure (2): $S$. marianum cell growth in suspension culture during 36 days on MS basal medium supplemented with 4.55M 2,4-D and $4.44 \mathrm{M}$ BA. Data are represented in mean \pm SE, values with same letter are not significantly different, at the 0.05 level, according to Duncan's multiple range test.

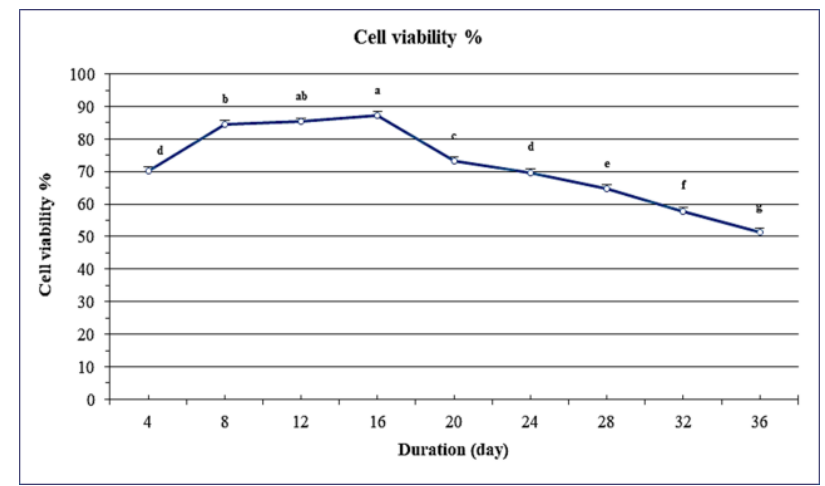

Figure (3): Cell viability in suspension culture of $S$. marianum during 36 days of incubation in MS basal medium supplemented with $4.55 \mu \mathrm{M}$ 2,4-D and $4.44 \mu \mathrm{M}$ BA. Data are represented in mean \pm SE, values with same letter are not significantly different, at the 0.05 level, according to Duncan's multiple range test.

\section{The impact of precursor feeding on biomass and secondary metabolite accumulation}

The effect of MS basal medium supplemented with $4.55 \mu \mathrm{M} 2,4-\mathrm{D}$ and $4.44 \mu \mathrm{M}$ BA, in addition to the different concentrations of the amino acid precursor; phenylalanine, on the fresh and dry weight of the cells of $S$. marianum cell suspension cultures is represented in Fig. (4). The fresh and dry weight of cells significantly increased by adding phenylalanine in the medium at $302.68 \mu \mathrm{M}$, compared to the control treatment without phenylalanine either in the solid or liquid medium. Higher concentrations of phenylalanine signifycantly decreased the fresh and dry weight of cells. Comparing the two control treatments without phenylalanine, it was obvious that the liquid medium produced significantly higher fresh and dry weight of cells than that of the solid medium. By calculating the water content in the cells according to the FW and DW, it ranged between $93.33 \%$ in the cells on the control solid medium and $96.36 \%$ in the suspended cells in the medium supplemented with $908.05 \mu \mathrm{M}$ phenylalanine.

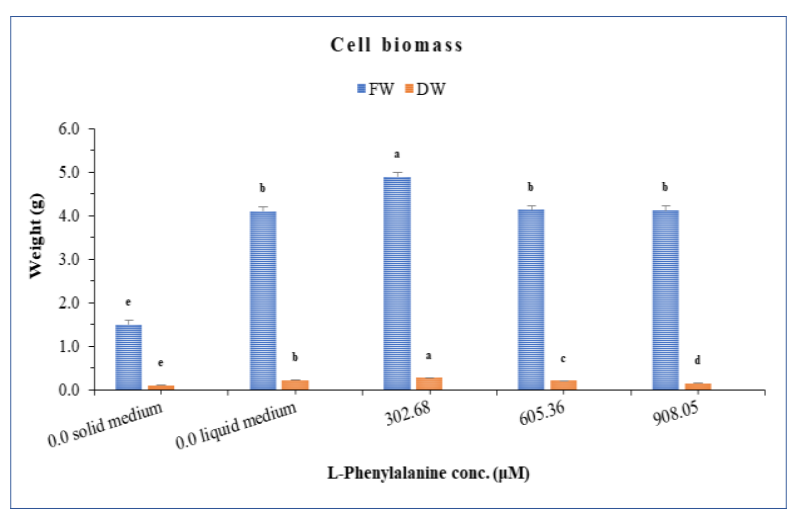

Figure (4): Effect of L-phenylalanine supplement on cell biomass of $S$. marianum suspension cultures. Data are represented in mean \pm SE, values with same letter are not significantly different, at the 0.05 level, according to Duncan's multiple range test.

Table (1) shows the content of several phenolic compounds in $S$. marianum suspended cells in MS basal medium supplemented with $4.55 \mu \mathrm{M} 2,4-\mathrm{D}$ and $4.44 \mu \mathrm{M}$ BA, in addition to different concentrations of phenylalanine. Phenylalanine application had a positive effect on the accumulation of some phenolic compounds. Catechin, coumaric acid and taxifolin attained their maximum accumulation on the lowest phenylalanine concentration $(302.68 \mu \mathrm{M})$, while chlorogenic acid and rutin were maximum on the highest concentration $(908.05 \mu \mathrm{M})$. Methyl gallate was not detected in all treatments, while very few amounts of coumaric acid, vanillin, cinnamic acid and kaempferol were detected in some treatments. Gallic acid, caffeic acid, syringic acid, ellagic acid and naringenin gained their maximum accumulation in the cells on the control solid medium, while pyrocatechol, vanillin and ferulic acid were the maximum in the suspended cells of the control liquid medium.

\section{DISCUSSION}

Callus of $S$. marianum was initiated from root segments of seedlings of in vitro germinated seeds. Friable callus was induced on MS basal medium supplemented with $4.55 \mu \mathrm{M} 2,4-\mathrm{D}$ and $4.44 \mu \mathrm{M}$ BA as reported in previous works of Hassanen and Khalil (2013) and Elsawy (2017). Callus induction is one of the most essential steps in initiating an in vitro system for the production of bioactive secondary metabolites from plants for industrial applications (Chandran et al., 2020). Cell suspension cultures are commonly used for industrial purposes due to their rapid growth, stable production, uniformity and the ease of scale-up the biomass production (Chandran et al., 2020).

Cell suspension cultures of $S$. marianum were established in the present study and the growth of cells was estimated using cell fresh weight and viability methods over a 36-day period. The growth of suspended cells displays a normal growth curve and cells started their 
Table (1): HPLC analysis of phenolic compounds exist in cells of $S$. marianum cell suspension cultures supplemented with different concentrations of L-phenylalanine as a supplement. Basal MS medium, in solid and liquid state were used as control.

\begin{tabular}{lccccc}
\hline \hline \multirow{2}{*}{$\begin{array}{c}\text { Concentration } \\
\text { of detected } \\
\text { Phenolic } \\
\text { compounds }(\%)\end{array}$} & $\begin{array}{c}\text { Control } \\
\text { solid } \\
\text { medium }\end{array}$ & \multicolumn{5}{c}{ L-phenylalanine conc. $(\boldsymbol{\mu M})$} \\
\cline { 2 - 6 } Liquid medium & \\
\hline Gallic acid & 0 & 0 & 302.68 & 605.36 & 908.05 \\
Chlorogenic acid & 0.143 & 0.138 & 0.139 & 0.068 & 0.136 \\
Catechin & 0.430 & 0.513 & 0.451 & 0.260 & 0.615 \\
Methyl gallate & 0.003 & 0.000 & 0.087 & 0.010 & 0.058 \\
Coffeic acid & 0.024 & 0.020 & 0.022 & 0.012 & 0.024 \\
Syringic acid & 0.014 & 0.009 & 0.007 & 0.004 & 0.008 \\
Pyrocatechol & 0.010 & 0.014 & 0.009 & 0.004 & 0.011 \\
Rutin & 0.000 & 0.000 & 0.149 & 0.081 & 0.160 \\
Ellagic acid & 0.246 & 0.114 & 0.081 & 0.047 & 0.085 \\
Coumaric acid & 0.008 & 0.007 & 0.008 & 0.003 & 0.006 \\
Vanillin & 0.004 & 0.005 & 0.003 & 0.002 & 0.003 \\
Ferulic acid & 0.016 & 0.026 & 0.019 & 0.010 & 0.025 \\
Naringenin & 1.638 & 1.428 & 1.157 & 0.770 & 1.624 \\
Taxifolin & 0.004 & 0.000 & 0.017 & 0.006 & 0.004 \\
Cinnamic acid & 0.001 & 0.001 & 0.000 & 0.000 & 0.001 \\
Kaempferol & 0.004 & 0.000 & 0.000 & 0.004 & 0.000 \\
\hline \hline
\end{tabular}

death phase after 16 days of culture. This may be explained by the death of cells that could be occurred by time due to nutrients depletion. Ramulifho et al. (2019) reported that the cell viability in cell suspension cultures increased until the cells reach the stationary phase, then the viability gradually decreased, which may indicate a change in the cellular metabolism as cells stop proliferating and the nutrients in the medium become limiting. It was reported that the growth of cells in suspension cultures can be assessed by several methods, including fresh and dry weight of cells, total cell number, packed cell number, cell viability and medium conductivity. It is recommended to perform any two methods to monitor the culture growth characterization (Evans et al., 2003) and fresh weight analysis is the most common and simple method with no need of sophisticated equipment (Mohamad and Abdullah, 2018).

Based on the analysis of growth curve carried out in the present study, the cells of $S$. marianum should be subcultured every 16-20 days for the maintenance and cells viability. The duration for maintaining cells in suspension cultures recorded differences based on the initial volume of cells, growth conditions and plant species (Ramulifho et al., 2019). For example, the medicinal plant; Abrus precatorius, suspended cells require subculturing every 14 days (Rahman et al., 2012), while Jatropha curcas and Jatropha gossypifolia cell suspensions require subculturing every 20 days (Ramos et al., 2013).

$S$. marianum cell suspension cultures offer an alternative source for liver protective drugs and would have a significant impact either pharmacologically and ecologically. Although S. marianum cell cultures can produce silymarin and phenolic compounds, the produced amounts are lower than that in the field grown plants (Abbasi et al., 2010). Moreover, the increasing demand for $S$. marianum worldwide for the pharmaceutical purposes is endangering its populations in the Mediterranean region (Ahmad et al., 2008). Therefore, the present study was directed towards using the precursor of the active constituents for better silymarin and certain phenolic compounds accumulation in cell cultures of $S$. marianum.

The precursor; phenylalanine has been reported to enhance secondary metabolite production in plant cell suspension cultures (Masoumian et al., 2011). In this study, the effect of phenylalanine feeding on biomass and secondary metabolites production in $S$. marianum cell suspension cultures was investigated. From the above results it was obvious that biomass and the concentration of silymarin and phenolic compounds content in cell suspension culture of $S$. marianum was strongly affected by phenylalanine concentration. The biomass expressed as fresh and dry weight of cells significantly increased by phenylalanine supplementation at $302.68 \mu \mathrm{M}$, compared to the control. Cellular proliferation in suspension cultures, which is expressed as biomass, is the first step for establishing a large-scale production of active compounds (Indu et al., 2013). Also, phenylalanine supplementation elevated the level of silymarin and some phenolic compounds. This may be caused by increasing metabolic flux through the phenylpropanoid biosynthetic pathway; however, appropriate concentration of the precursor should be applied for successful feeding (Rahimi et al., 2011). Phenylalanine caused a marked silymarin accumulation; it was significantly increased 
by increasing phenylalanine concentration. Phenylalanine elevated accumulation of silymarin by about 3fold at the highest concentration of $908.05 \mu \mathrm{M}$, compared to the callus on the control medium without phenylalanine. The application of phenylalanine as the biosynthetic precursor of phenylpropanoid pathway enhanced in vitro silymarin accumulation in $S$. marianum with $31.4 \%$ increase in callus at $25 \mu \mathrm{M}$ phenylalanine as reported by Elhaak et al. (2016) and with 1.89 -fold increase in hairy root culture at $10 \mu \mathrm{M}$ phenylalanine, compared to the control as found by Rahimi et al. (2011). Also, phenylalanine was frequently used in vitro as a precursor, such as enhancing in vitro production of isoflavones from Psoralea corylifolia cell cultures (Shinde et al., 2009a), flavonoid from Hydrocotyle bonariensis (Masoumian et al., 2011) and phenolic acids from Exacum affine (Skrzypczak-Pietraszek et al., 2014).

In this study, supplementing the media with different concentrations of phenylalanine resulted in a broad variation in the phenolic content and consequently will affecting the antioxidant activity of $S$. marianum cell culture extract. Antioxidant activity is considered the most important link associated with the phenolic content of the plant cell and tissue (Fidranny et al., 2015; Hano and Tungmunnithum, 2020). The results are in harmony with that of Tůmová et al. (2006), who concluded that feeding $S$. marianum cell cultures in vitro with coniferyl alcohol; the precursor of biosynthetic pathway of flavonolignans, enhances the accumulation of some components of silymarin complex and flavonoid-taxifolin and does not influenced the other components. Gad et al. (2021) reported that coniferyl alcohol and taxifolin are may be synthesized in vitro from dicaffeoylquinic acid by caffeoyl-CoA pathway.

The suggested pathway for silybin biosynthesis, from dicaffeoylquinic acid, starts from coniferyl alcohol and taxifolin as substrates for flavonolignane biosynthesis. Coniferyl alcohol and taxifolin are synthesized through the p-coumaroyl-CoA and caffeoyl-CoA pathways. This pathway involves a series of enzymes. In the same way, Shinde et al. (2009b) reported that phenylalanine at $2 \mathrm{mM}$ concentration enhanced isoflavones levels in Psoralea corylifolia hairy root cultures, compared to the control, however isoflavones production was inhibited when 10 $\mathrm{mM}$ phenylalanine was applied. The reason for the enhanced accumulation of silymarin after phenylalanine feeding (as a biosynthesis precursor), while some phenolic compounds were not affected could be that some precursors are not completely soluble in aqueous media and therefore the reaction rate could fairly be detected (Tůmová et al., 2006). Also, Gad et al. (2021) reported a well-documented phenomenon of the increase of peroxidase activity in elicited in vitro cell cultures that cause the degradation of secondary metabolites and may contribute to their low amounts.

The first step in the phenylpropanoid pathway is catalysed by phenylalanine ammonia lyase, which converts phenylalanine to ammonia and trans-cinnamic acid (PAL).Therefore, phenylalanine is involved in the biosynthesis of flavonoids, phenyl-propanoids and lignins in plants (Solekha et al., 2020). On this base, the results obtained in the present study indicated that all the three concentrations of added phenylalanine may stimulated PAL activity and consequently supported the use of this precursor as the substrate for the first step of phenylpropanoid pathway (Rahimi et al., 2011).

\section{CONCLUSION}

The production of silymarin and other phenolic compounds in $S$. marianum cell suspension cultures was considerably boosted when the precursor amino acid L-phenylalanine was used. In the $S$. marianum cell suspension culture system, this approach provides an alternative method for large-scale synthesis of bioactive secondary metabolites. This can also help in preventing the plant from becoming endangered due to the overcollection of plant material for extracting bioactive compounds. Interestingly, $S$. marianum cell suspension culture has the potential to scale up to the level of the bioreactor for enhancing the production of silymarin-rich extracts for possible commercial use.

\section{REFERENCES}

ABBASI, B., M. KHAN, T. MAHMOOD, M. AHMAD, M. CHAUDHARY AND M. KHAN. 2010. Shoot regeneration and free-radical scavenging activity in Silybum marianum L. Plant Cell Tissue Organ Cult. 101: 371-376. https://doi.org/10.1007/s11240-010-9692-x

ABENAVOLI, L., A.A. IZZO, N. MILI'C, C. CICALA, A. SANTINI AND R. CAPASSO. 2018. Milk thistle (Silybum marianum): A concise overview on its chemistry, pharmacological, and nutraceutical uses in liver diseases. Phyther. Res. 32: 2202 2213. https://doi.org/10.1002/ptr.6171

ABOUZID, S.F., S. CHEN AND G.F. PAULI. 2016. Silymarin content in Silybum marianum populations growing in Egypt. Ind. Crops Prod. 83: 729-737. https://doi.org/10.1016/j.indcrop.2015.12.012

AHMAD, M., M.A. KHAN, A. HASAN, M. ZAFAR AND S. SULTANA. 2008. Chemotaxonomic standardization of herbal drugs milk thistle and globe thistle. Asian J. Chem. 20 (6): 4443-4459.

BHATTACHARYA, S. 2020. Milk Thistle Seeds in Health. Chapter 30: 429-438. In "Nuts and Seeds in Health and Disease Prevention (Second Edition)". Edited by: Preedy V.R. and R.R. Watson. Elsevier Inc.

https://doi.org/10.1016/B978-0-12-8185537.00030-9

BIJAK, M. 2017. Silybin, a major bioactive component of milk thistle (Silybum marianum L. Gaernt.) -chemistry, bioavailability, and metabolism. Molecules 22 (11): 1942.

https://doi.org/ 10.3390/molecules22111942

BIJAK, M., R. SZELENBERGER, J. SALUK AND 
P. NOWAK. 2017. Flavonolignans inhibit ADP induced blood platelets activation and aggregation in whole blood. Int. J. Biol. Macromol., 95: 682688.

https://doi.org/10.1016/j.ijbiomac.2016.12.002

BOULOS, L. 2002. Flora of Egypt. Verbenaceae Compositae. Vol. 3, Al Hadara Publishing, Cairo, Egypt, pp. 157-159.

CACHO, M., M. MORAN, P. CORCHETE AND J. FRARANDEZ-TARRAGO. 1999. Influence of medium composition on the accumulation of flavonolignans in cultured cells of Silybum marianum (L.) Gaertn. Plant Sci. 144: 63-68.

CHANDRAN, H., M. MEENA, T. BARUPAL AND K. SHARMA. 2020. Plant tissue culture as a perpetual source for production of industrially important bioactive compounds. Biotechnol. Rep. 26: e00450. https://doi.org/10.1016/j.btre.2020.e00450

COLICA, C., L. BOCCUTO AND L. ABENAVOLI. 2017. Silymarin: an option to treat non-alcoholic fatty liver disease. World J. Gastroenterol. 23 (47): 8437-8438.https://doi.org/10.3748/wjg.v23.i47.8437

CSUPOR, D., A. CSORBA, J. HOHMANN, D.D. CUSPOR, A. CSORBA AND J. HOHMANN. 2016. Recent advances in the analysis of flavonolignans of Silybum marianum. J. Pharm. Biomed. Anal. 130: 301-317. https://doi.org/ 10.1016/j.jpba.2016.05.034

ELHAAK, M., M. ZAYED, M. MATTAR, D. GAD AND K. DIETZ. 2016. Optimization of Silybum marianum L. callus production and magnifying callus silymarin accumulation by elicitors or precursors. Int. J. Adv. Pharm. Biol. Chem. 5 (2): 148-163.

ELLNAIN-WOJTASZEK, M. AND G. ZGÓRKA. 1999. High-performance liquid chromatography and thin-layer chromatography of phenolic acids from Ginkgo biloba L. leaves collected within vegetative period. J. Liq. Chromatogr. Relat. Technol. $22 \quad$ (10): $1457-1471$. https://doi.org/10.1081/JLC-100101744

ELSAWY, A.M. 2017. Genetic diversity of Silybum marianum (L.) Gaertn. and in vitro production of silymarin. Dessertation, Faculty of Science, University of Al-Azhar for Girls, Cairo, Egypt.

EVANS, D., J. COLEMAN AND A. KEARNS. 2003. Plant Cell Culture: The Basics. Taylor and Francis, London.

FIDRANNY, I., A. SUKOWATI AND S. SUKRASNO. 2015. In vitro antioxidant activities of various leaves extracts from five varieties of Rambutan (Nephelium lappaceum) and its correlation with total flavonoid, phenolic, carotenoid content. Asian J. Pharm. Clin. Res. 8 (2): 139-143.

FIROUZI, A., S.A. MOHAMMADI, M. KHOSROWCHAHLI, A. MOVAFEGHI AND T. HASANLOO. 2013. Enhancement of silymarin production in cell culture of Silybum marianum (L) Gaertn by elicitation and precursor feeding. J.
Herbs Spices Med. Plants, 19 (3): 262-274. https://doi.org/10.1080/10496475.2013.791908

GAD, D., H. EL-SHORA, D. FRATERNALE, E. MARICCHIOLO, A. POMPA AND K.J. DIETZ. 2021. Bioconversion of callus-produced precursors to silymarin derivatives in Silybum marianum leaves for the production of bioactive compounds. Int. J. Mol. Sci. $22 \quad$ (4): 2149. https://doi.org/10.3390/ijms22042149

GENG, S., M. MA, H.C. YE, B.Y. LIU, G.F. LI AND K. CONG. 2001. Effect of ipt gene expression on the physiological and chemical characteristics of Artemisia annua L. Plant Sci. 160 (4): 691-698.

HANO, C. AND D. TUNGMUNNITHUM. 2020. Plant polyphenols, more than just simple natural antioxidants: oxidative stress, aging and agerelated diseases. Medicines 7 (5): 26. https://dx.doi.org/10.3390\%2Fmedicines7050026

HASSANEN, S.A. AND R.M.A. KHALIL. 2013. In vitro production and biochemical analysis of silymarin from Silybum marianum plant. World Appl. Sci. J. 22 (1): 26-34.

INDU, S., L. VIJAYA, B. MEETA, V. JOSSY AND C. NARESH. 2013. Production of flavonoids in callus culture of Anthocephalus indicus A. Rich. Asian J. Plant Sci. 12 (1): 40-45. https://dx.doi.org/10.3923/ajps.2013.40.45

MASOUMIAN, M., A. ARBAKARIYA, A. SYAHIDA AND M. MAZIAH. 2011. Effect of precursors on flavonoid production by Hydrocotyle bonariensis callus tissues. Afr. J. Biotechnol. 10: 6021-6029.

MATKOWSKI, A. 2008. Plant in vitro culture for the production of antioxidants - A review. Biotech. Advances $\quad 26 \quad$ (6): $\quad 548-560$. https://doi.org/10.1016/j.biotechadv.2008.07.001

MOHAMAD, P.N.I. AND T.A. ABDULLAH. 2018. Monitoring the growth of plant cells in suspension culture. In A. Amid, S. Sulaiman, D. Jimat and N. Azmin (Eds.), Multifaceted Protocol in Biotechnology. Springer, Singapore.

MURASHING, T. AND F. SKOOG. 1962. A revised medium for rapid growth and bioassays with tobacco tissue cultures. Plant Physiol. 15: 473-497.

RAMOS, L.Y.S., L.M. CARBALLO AND M.V. MELARA. 2013. Establishment of cell suspension cultures of two Costa Rican Jatropha species (Euphorbiaceae). Rev. Biol. Trop. 61 (3): 10951107. https://doi.org/10.15517/RBT.V61I3.11906

RAHIMI, S., T. HASANLOO, F. NAJAFI AND R.A. KHAVARI-NEJAD. 2011. Enhancement of silymarin accumulation using precursor feeding in Silybum marianum hairy root cultures. Plant Omics, 4 (1): 34-39.

RAM, G., M.K. BHAN, K.K. GUPTA, B. THAKER, U. JAMWAL AND S. PAL. 2005. Variability pattern and correlation studies in Silybum marianum Gaertn. Fitoterapia 76 (2): 143147. https://doi.org/10.1016/j.fitote.2004.10.006

RAHMAN, M.S., M.A.B. MIAH, M.S. HOSSAIN, 
A.H. KABIR AND M.M. RAHMAN. 2012. Establishment of cell suspension culture and plant regeneration in Abrus precatorius L., a rare medicinal plant. Not. Sci. Biol. 4 (1): 86-93. https://doi.org/10.15835/nsb417187

RAMULIFHO, E., T. GOCHE, A.J. VAN, T.J. TSILO, S. CHIVASA AND R. NGARA. 2019. Establishment and characterization of callus and cell suspension cultures of selected Sorghum bicolor (L.) moench varieties: a resource for gene discovery in plant stress biology. Agronomy 9 (5): 218. https://doi.org/10.3390/agronomy9050218

SHAH, M., M.A. ULLAH, S. DROUET, M. YOUNAS, D. TUNGMUNNITHUM, N. GIGLIOLI-GUIVARC'H, C. HANO AND B.H. ABBASI. 2019. Interactive effects of light and melatonin on biosynthesis of silymarin and antiinflammatory potential in callus cultures of Silybum marianum (L.) Gaertn. Molecules 24 (7): 1207.https://doi.org/10.3390\%2Fmolecules 240712 $\underline{07}$

SHAH, M., H. JAN, S. DROUET, D. TUNGMUNNITHUM, J.H. SHIRAZI, C. HANO AND B.H. ABBASI. 2021. Chitosan elicitation impacts flavonolignan biosynthesis in Silybum marianum (L.) Gaertn cell suspension and enhances antioxidant and anti-Inflammatory activities of cell extracts. Molecules $26 \quad$ (4): 791. https://doi.org/10.3390/molecules26040791

SHINDE, A.N., N. MALPATHAK AND D.P. FULZELE. 2009a. Optimized production of isoflavones in cell cultures of Psoralea corylifolia L. using elicitation and precursor feeding. Biotechnol. Bioprocess Eng. 14: 612-618. https://doi.org/10.1007/s12257-008-0316-9

SHINDE, A.N., N. MALPATHAK AND D.P. FULZELE. 2009b. Enhanced production of phytoestrogenic isoflavones from hairy root cultures of Psoralea corylifolia L. using elicitation and precursor feeding. Biotechnol. Bioprocess Eng. 14: 288-294. https://doi.org/10.1007/S12257-0080238-6

SKRZYPCZAK-PIETRASZEK, E., J. SŁOTA AND
J. PIETRASZEK. 2014. The influence of Lphenylalanine, methyl jasmonate and sucrose concentration on the accumulation of phenolic acids in Exacum affine Balf. f. ex Regel shoot culture. Acta Biochim. Pol. 61 (1): 47-53.

SOLEKHA, R., F.A. SUSANTO, T. JOKO, T.R. NURINGTYAS AND Y.A. PURWESTRI. 2020. Phenylalanine ammonia lyase (PAL) contributes to the resistance of black rice against Xanthomonas oryzae pv. oryzae. J. Plant Pathol. 102 (2): 359365. https://doi.org/10.1007/s42161-019-00426-z

SOTO, C., J. PÉREZ, V. GARCÍA, E. URÍA, M. VADILLO AND L. RAYA. 2010. Effect of silymarin on kidneys of rats suffering from alloxan-induced diabetes mellitus. Phytomedicine 17 (14): 1090-1094. https://doi.org/10.1016/j.phymed.2010.04.011

VALKOVÁ, V., H. ĎÚRANOVÁ, J. BILČÍKOVÁ AND M. HABÁN. 2020. Milk thistle (Silybum marianum): a valuable medicinal plant with several therapeutic purposes. J. Microbiol. Biotech. Food Sci. 9 (4): 836-843. https://doi.org/10.15414/jmbfs.2020.9.4.836-843

VARGAS-MENDOZA, N., E. MADRIGALSANTILLAN, A. MORALES-GONZALEZ AND J. ESQUIVEL-SOTO. 2014. Hepatoprotective effect of silymarin. World J. Hepatol. 6 (3): 144149. https://dx.doi.org/10.4254\%2Fwjh.v6.i3.144

STODDART, M.J. 2011. Mammalian cell viability: Methods and protocols. In Methods in Molecular Biology. Vol. 740, Springer Science+Business Media, LLC.

TŮMOVÁ, L., J. ŘIMÁKOVÁ, J. TƯMA AND J. DUŠEK. 2006. Silybum marianum in vitroflavonolignan production. Plant Soil Environ. 52 (10): 454-458. https://doi.org/10.17221/3466-PSE

ZHAO, J. AND R. VERPOORTE. 2007. Manipulating indole alkaloid production by Catharanthus roseus cell cultures in bioreactors: from biochemical processing to metabolic engineering. Phytochem. Rev. 6 (2): 435-457. http://dx.doi.org/10.1007/s11101-006-9050-0 


\title{
تراكم السيليمارين في المزارع المعلقة لنبات شوك الجمل عن طريق التغذية ببادئ
}

\author{
صباح أنور حسانين، محمد إسماعيل دياب، غادة عبد المنعم حجازي"، جميل ريان أبو الايس الايس

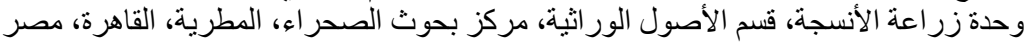

\section{الملخص العربـــي}

السيليمارين والمركبات الفينولية لها العديد من الاستخدامات الصيدلانية، لا سيما كعوامل واقية من مرض الكبد. ويعتبر محتوى السيليمارين في ثمار

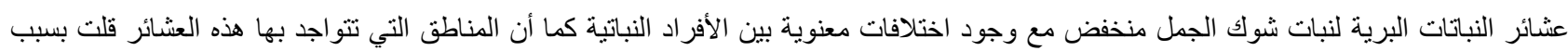

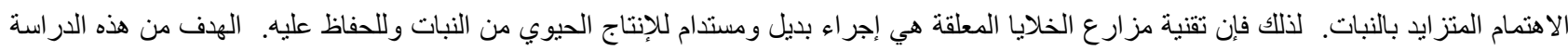

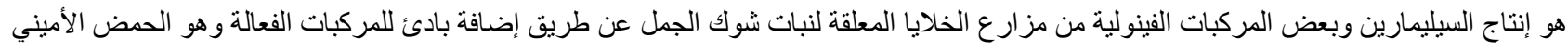

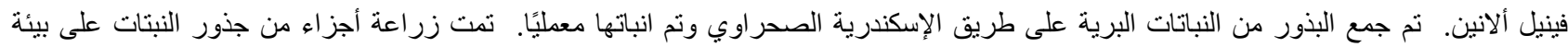

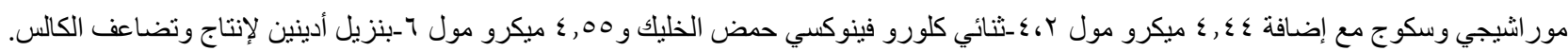

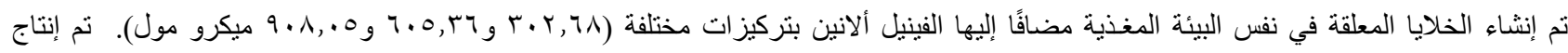

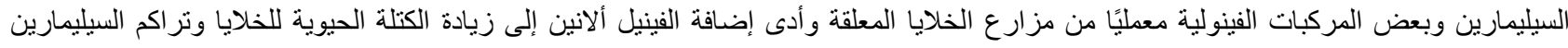

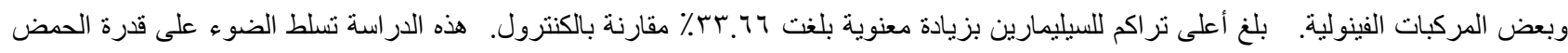
الأميني فينيل ألانين كبادئ للسيليمارين في تعزيز إنتاج المستخلصات الغنية بالسيليمارين من مزارع الخلايا المعلقة لنبات شوك الجمل وحماية الفلورا والتنوع الحيوي من خلال منع التجميع الجائر للنبات وكذلك التحكم في كمية الإنتاج ونو عيته ووقتته. 